\title{
Intestinal parasites of zoonotic importance in dogs from the District of General Pueyrredón (Buenos Aires, Argentina)
}

\author{
Lavallén, C.M. ${ }^{\text {a; }}$ Dopchiz, M.C. ; Lobianco, E. ; Hollmann, P. ; Denegri, G. ${ }^{\text {a }}$
}

${ }^{a}$ Laboratorio de Zoonosis Parasitarias, Departamento de Biología, Facultad de Ciencias Exactas y Naturales, Universidad Nacional de Mar del Plata, Funes 3350, Mar del Plata (7600), Argentina. Consejo Nacional de Investigaciones Científicas y Técnicas (CONICET), Argentina. ${ }^{b}$ Centro Municipal de Zoonosis, Municipalidad de General Pueyrredón, Hernandarias 10200, Mar del Plata (7600), Argentina. Corresponding author: Lic. Carla Lavallén. Tel.: 5402234752426 int 450; fax: 540223475 3150. E-mail: carla_lavallen@hotmail.com.

\begin{abstract}
Lavallén, C.M.; Dopchiz, M.C.; Lobianco, E.; Hollmann, P.; Denegri, G.: Intestinal parasites of zoonotic importance in dogs from the District of General Pueyrredón (Buenos Aires, Argentina). Rev. vet. 22: 1, 19-24, 2011. Dog feces harbouring infective parasitic forms (larves, eggs, cysts of helminths and oocysts of protozoan) are potential sources of environmental contamination, representing a high risk of infection for people. The feces of 46 dogs housed at the Municipal Centre of Zoonoses of Mar del Plata City were analyzed to determine the prevalence of intestinal parasitic forms. The overall prevalence of parasites was 89.13\%. Detected parasites were Ancylostoma caninum (71.74\%), Toxocara canis (63.04\%), Trichuris vulpis (45.65\%), Uncinaria stenocephala (41.30\%), Capillaria aerophila (17.39\%), Echinococcus granulosus (8.69\%), Giardia spp. (10.87\%) and Isospora spp. (2.17\%). The geographical characteristics and the wet weather of the region under consideration, together with the cultural habits and the socio-economic situation of the population may favor transmission. The prevalences of stray and domesticated infected dogs were $88 \%$ and $95.24 \%$, respectively. Because stray dogs are often free-roaming, environmental contamination with parasite forms had likely already occurred. The prevalences of A. caninum and T. vulpis were significantly higher in $<6$ years-old dogs rather than in older animals. Parasite-specific immunity is usually acquired during development, probably as a consequence of single or repeated exposures. Multiple infections were more frequent $(80 \%)$ than infections with a single parasite (20\%) and the most common parasite association $(21.87 \%)$ was among $A$. caninum, T. vulpis, T. canis and U. stenocephala. The high prevalence of poly-parasitized animals together with the zoonotic potential of the parasites found in the samples, indicate that dog feces could be the source of several parasite infections for human as well as canine populations of the region under study. The parasite zoonoses transmitted by dogs are still a sanitary problem in the District of General Pueyrredón.
\end{abstract}

Key words: dog, intestinal parasites, zoonoses.

\begin{abstract}
Resumen
Lavallén, C.M.; Dopchiz, M.C.; Lobianco, E.; Hollmann, P.; Denegri, G. Parásitos intestinales de importacia zoonótica en perros del Partido de General Pueyrredón (Buenos Aires, Argentina). Rev. vet. 22: 1, 19-24, 2011. La materia fecal canina que contiene formas parasitarias infectivas (larvas, huevos, quistes de helmintos y ooquistes de protozoos) es una fuente potencial de contaminación ambiental, representando un importante riesgo para las personas. Las heces de 46 caninos albergados en el Centro Municipal de Zoonosis de la ciudad de Mar del Plata, fueron analizadas para determinar la presencia de formas parasitarias intestinales. La prevalencia general de parásitos fue 89,13\%. Los parásitos hallados fueron Ancylostoma caninum (71,74\%), Toxocara canis (63,04\%), Trichuris vulpis $(45,65 \%)$, Uncinaria stenocephala (41,30\%), Capillaria aerophila (17,39\%), Echinococcus granulosus (8,69\%), Giardia spp. (10,87\%) e Isospora spp. (2,17\%). Las características geográficas y el clima húmedo de la región de estudio sumado a los hábitos culturales y la situación socioeconómica de la población, pueden favorecer la transmisión de parásitos. La prevalencia de perros callejeros y domésticos infectados fue $88 \%$ y $95,24 \%$ respectivamente. Debido a que los perros callejeros deambulan frecuentemente por las calles, es altamente probable que se genere contaminación ambiental con formas parasitarias. Las prevalencias de A. caninum
\end{abstract}




\begin{abstract}
y T. vulpis fueron significativamente elevadas en perros menores de 6 años. La inmunidad parasitaria específica es adquirida con la edad probablemente como consecuencia de una o sucesivas exposiciones a parásitos. Las infecciones múltiples fueron más frecuentes $(80 \%)$ que las infecciones con un solo parásito $(20 \%)$ y la asociación parasitaria más frecuente (21,87\%) fue entre A. caninum, T. vulpis, T. canis y U. stenocephala. La elevada prevalencia de animales poliparasitados sumado al potencial zoonótico de los parásitos hallados en las muestras, indicaría que las heces caninas pueden ser fuente de diversas infecciones parasitarias para las poblaciones humana y canina de la región de estudio. Las zoonosis parasitarias transmitidas por caninos siguen siendo todavía un problema sanitario en el Partido de General. Pueyrredón.
\end{abstract}

Palabras clave: canino, parásitos intestinales, zoonosis.

\section{INTRODUCTION}

The ubiquitous distribution of dogs around the world and the vast differences in their roles, have lead to their exposure to infectious organisms and their unwitting participation in the transmission of over 60 zoonotic infections ${ }^{18}$.

Dogs are definitive hosts for several endoparasites with zoonotic potential such as A. caninum, T. canis, T. vulpis, C. aerophila, E. granulosus, Giardia spp., or coccidians like Cryptosporidium spp. Dog faeces harbouring infective parasitic forms (larves, eggs, cysts of helminths and oocysts of protozoan) are potential sources of environmental contamination representing a high risk of infection for the people and therefore have been recognized as a significant public health problem worldwide, especially in developing countries and communities that are socioeconomically disadvantaged ${ }^{11,28}$.

In Mar del Plata city there are between 10,00012,000 stray dogs and one domesticated dog each four or five inhabitants. This situation generates a huge contamination of the city with dog faeces ${ }^{26}$. The District of General Pueyrredón counts with the Municipal Centre of Zoonoses (MCZ) which performs dog and cat castrations and also shelters stray and biting dogs, among others activities.

The knowledge of parasites with sanitary importance brings the possibility to estimate the parasitic situation of the region in order to design or intensify prevention strategies about this environmental problem. Therefore, the objective of this study was to determine the prevalence of parasites in faeces of dogs being kept in the MCZ of Mar del Plata city by coprological procedures and coproantigen tests. We evaluated parasite prevalences regarding the gender, age, origin of the dogs and mixed infections.

\section{MATERIALS AND METHODS}

Study area and design. A descriptive study was carried out during autumn 2004 in Mar del Plata and Batán, two of the most important cities of General Pu- eyrredón District, with an area of $1,453 \mathrm{~km}^{2}$ and located on the southeast coast of Buenos Aires Province, Argentina $\left(38^{\circ} \mathrm{S} ; 57^{\circ} 33^{\prime} \mathrm{W}\right.$ ) (Figure 1). The total population reported for the District in 2010 was 614,350 inhabitants, most of the people live in the area under study ${ }^{8}$. The rest of the population is distributed in small villages and in rural areas.

Source of samples and parasitological procedures. Between May and June 2004, 46 samples of fresh dog faeces were collected from the MCZ and conserved in plastic containers in duplicate (groups A and B). Group A was conserved with $10 \%$ formaldehyde and group B was frieze without preservatives until its utilization. For each dog an epidemiological file was kept with the following information: sex, age, breed, origin and reason for admission to the centre. The samples of group A were processed in the parasitological laboratory of the MCZ by Ritchie sedimentation method and Sheather flotation method ${ }^{21}$. The samples processed by the Ritchie method were stained by the modified Ziehl Neelsen procedure and modified safranin technique for the identification of oocysts of coccidians ${ }^{7}$. With each sample, two slides were made and microscopically examined at 100x, 400x and 1,000x amplifications. Identification of parasites was performed by morphological

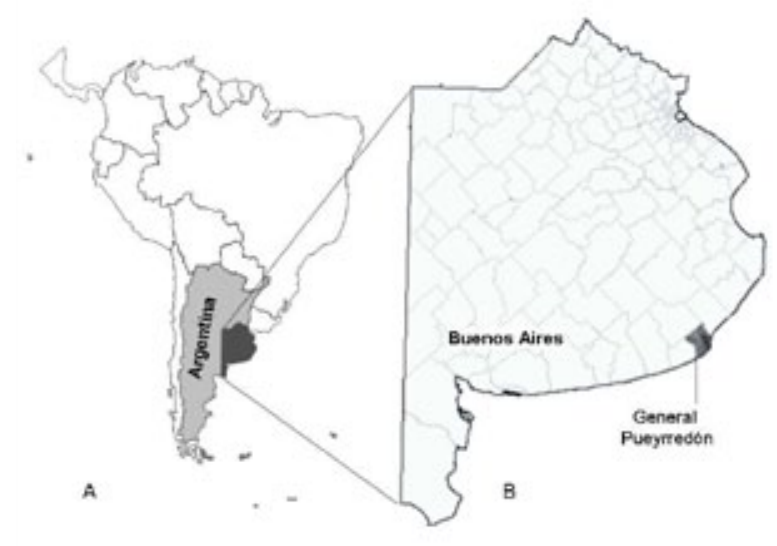

Figure 1. Geographic location. A. Argentina in South America and Buenos Aires Province in Argentina. B. Location of the District of General Pueyrredón. 
characteristics. A sample was recorded as positive if at least one parasitic form was observed by any method.

To the coproantigen determination the group $\mathrm{B}$ of samples was kept at $-20^{\circ} \mathrm{C}$ for 20 days and then was sent to the Regional Laboratory of Environmental Health from Bariloche (Argentina), following the general indications to transport biological material. All the positive samples determined by the Copro-ELISA test were processed through the confirmation test CoproWestern Blot to identify E. granulosus, following standard techniques ${ }^{2,15}$, in the Parasitological Unit of the National Institute of Microbiology "Carlos Malbrán" (Buenos Aires, Argentina). This diagnostic system was considered undetermined when Copro-ELISA was positive and Copro-WESTERN BLOT was negative and it was considered positive when both techniques were positive.

Data analysis. Data analysis was performed using EpiInfo 3.3.2 (CDC, Atlanta, USA) and SPSS 11.5. The comparisons of prevalences between dichotomous categories (stray dogs versus domiciliary dogs, male versus female, and $<6$-year-old versus $>6$-year-old) were made using the Fisher Exact test for two qualitative variables ${ }^{23}$. It was considered statistically significant when $\mathrm{p}<0.05$.

\section{RESULTS}

The analysis of the epidemiological files evidenced the following data: from the total of dogs kept in the MCZ $76.10 \%$ were male and $23.90 \%$ female; $93.40 \%$ were mixed-breed dogs and $6.66 \%$ pure-breed; the ages oscillated from two to nine years-old; the $54.40 \%$ used to be stray dogs and the $45.60 \%$ pet dogs; the $67.30 \%$ entered to the MCZ for being biting dogs and the $32.70 \%$ for being abandoned.

The overall prevalence of parasites was $89.13 \%$ among the 46 faecal samples analyzed. The most frequently observed parasite was $A$. caninum $(71.74 \%)$, followed by T. canis (63.04\%), T. vulpis (45.65\%), $U$. stenocephala $(41.30 \%)$, C. aerophila $(17.39 \%)$ and others with minor percentages (Table 1).

The faecal samples analyzed trough copro ELISA + Western blot to identify E. granulosus, evidenced 4 $(8.69 \%)$ samples positive and $2(4.35 \%)$ undetermined. One of the positive samples also had Taenid eggs.

Among the total of stray and domiciliary dogs sheltered in the MCZ, the $88 \%$ and the $95.24 \%$ respectively were infected with at least one parasite. The specific prevalences were similar between the two populations (Table 2).

In regard to gender, there was no significant difference in the overall prevalence between males and females $(88.57 \%$ versus $90.90 \%)$, and the prevalence of each parasite was similar between the genders (Table 3).

The general prevalence between age categories showed no significant difference $(96.80 \%$ versus $73.30 \%$ ). However the prevalences of A. caninum and $T$. vulpis were significantly higher in $<6$ years-old dogs
Table 1. General and relative prevalence of parasitic agents in faece

\begin{tabular}{lccc}
\hline parasites & $\begin{array}{c}\text { number of } \\
\text { positive } \\
\text { samples }\end{array}$ & $\begin{array}{c}\text { general } \\
\text { prevalence } \\
(\mathrm{n}=46)(\%)\end{array}$ & $\begin{array}{c}\text { relative } \\
\text { prevalence }^{\mathrm{b}} \\
(\mathrm{n}=41)(\%)\end{array}$ \\
\hline
\end{tabular}

helminths

\begin{tabular}{|c|c|c|c|}
\hline A. caninum & 33 & 71.74 & 80.49 \\
\hline T. canis & 29 & 63.04 & 70.73 \\
\hline T. vulpis & 21 & 45.65 & 51.22 \\
\hline U. stenocephala & 19 & 41.30 & 46.34 \\
\hline C. aerophila & 8 & 17.39 & 19.51 \\
\hline E. granulosus ${ }^{\mathrm{c}}$ & 4 & 8.69 & 9.76 \\
\hline total $^{\mathrm{d}}$ & 41 & 89.13 & 100 \\
\hline
\end{tabular}

protozoan

$\begin{array}{rlcc}\text { Giardia } \text { spp. } & 5 & 10.87 & 12.19 \\ \text { Isospora } \text { spp. } & 1 & 2.17 & 2.43 \\ \text { total }^{\mathrm{d}} & 6 & 13.04 & 14.63\end{array}$

${ }^{\text {a }}$ general prevalence was estimated in relation to total number of samples analyzed.

${ }^{\mathrm{b}}$ relative prevalence was estimated in relation to total number of positive samples.

${ }^{c}$ prevalence of parasites was estimated taking account positive results in the Copro-ELISA and the Copro-Western Blot tests.

${ }^{\mathrm{d}}$ more than 1 parasite agent can be present in a single sample.

Table 2. Comparison of the specific prevalences in faeces of stray and domiciliary dog

\begin{tabular}{|c|c|c|c|}
\hline \multirow[b]{2}{*}{ parasites } & \multicolumn{3}{|c|}{ source of dogs } \\
\hline & $\begin{array}{l}\text { stray dogs a } \\
(\mathrm{n}=25)(\%)\end{array}$ & $\begin{array}{c}\text { domiciliary } \\
\text { dogs }{ }^{\mathrm{b}} \\
(\mathrm{n}=21)(\%)\end{array}$ & $X^{2}$ \\
\hline A. caninum & 72 & 71.43 & 0.002 \\
\hline T. canis & 60 & 66.66 & 0.104 \\
\hline T. vulpis & 40 & 52.38 & 0.705 \\
\hline U. stenocephala & 40 & 42.86 & 0.038 \\
\hline C. aerophila & 16 & 19.05 & 0.074 \\
\hline E. granulosus $^{\mathrm{c}}$ & 8 & 9.52 & 0.526 \\
\hline Giardia spp. & 16 & 4.76 & 1.488 \\
\hline Isospora spp. & 0 & 4.76 & 1.217 \\
\hline total $^{\mathrm{d}}$ & 88 & 95.24 & 0.753 \\
\hline
\end{tabular}

${ }^{a}$ prevalence of parasites was estimated in relation to total number of stray dogs.

${ }^{\mathrm{b}}$ prevalence of parasites was estimated in relation to total number of domiciliary dogs.

${ }^{c}$ prevalence of parasites was estimated taking account positive results in the Copro-ELISA and the Copro-Western Blot tests.

${ }^{\mathrm{d}}$ more than 1 parasite agent can be present in a single sample.

than in older dogs $\left(83.90 \%\right.$ versus $46.70 \% ; X^{2}=6.901$, $\mathrm{p}=0.0248$ and $61.3 \%$ versus $13.30 \% ; X^{2}=9.370, \mathrm{p}=$ 0.0046) (Table 3).

Multiple infections were remarkably more frequent $(80 \%)$ than infections with a single parasite $(20 \%)$ and 
Table 3. Comparison of the specific prevalences in dogs by gender and age.

\begin{tabular}{|c|c|c|c|c|c|c|}
\hline \multirow[b]{2}{*}{ parasites } & \multicolumn{3}{|c|}{ gender $^{\mathrm{a}}$} & \multicolumn{3}{|c|}{ age categories ${ }^{b}$} \\
\hline & $\begin{array}{c}\text { male } \\
(\mathrm{n}=35)(\%)\end{array}$ & $\begin{array}{c}\text { female } \\
(\mathrm{n}=11)(\%)\end{array}$ & $X^{2}$ & $\begin{array}{c}2-5 \text { years } \\
(\mathrm{n}=31)(\%)\end{array}$ & $\begin{array}{c}6-9 \text { years } \\
(\mathrm{n}=15)(\%)\end{array}$ & $X^{2}$ \\
\hline A. caninum & 68.57 & 81.81 & 0.724 & 83.90 & 46.70 & $6.901 *$ \\
\hline T. canis & 77.14 & 63.63 & 0.792 & 80.60 & 60 & 2.234 \\
\hline T. vulpis & 48.57 & 36.36 & 0.503 & 61.30 & 13.30 & $9.370^{*}$ \\
\hline U. stenocephala & 40 & 45.45 & 0.103 & 51.60 & 20 & 4.167 \\
\hline C. aerophila & 14.28 & 27.27 & 0.983 & 16.10 & 20 & 0.105 \\
\hline E. granulosus ${ }^{\mathrm{c}}$ & 11.42 & 0 & 2.169 & 4.35 & 4.35 & 0.950 \\
\hline Giardia spp. & 5.71 & 27.27 & 4.015 & 13.30 & 9.70 & 0.139 \\
\hline Isospora spp. & 2.85 & 0 & 0.321 & 3.20 & 0 & 0.495 \\
\hline total $^{\mathrm{d}}$ & 88.57 & 90.90 & 0.003 & 96.80 & 73.30 & 5.733 \\
\hline
\end{tabular}

${ }^{a}$ prevalence of parasites was estimated in relation to total number of males and females.

${ }^{\mathrm{b}}$ prevalence of parasites was estimated in relation to total number of dogs younger than 6 years-old and older than 6 years-old. ${ }^{\mathrm{c}}$ prevalence of parasites was estimated taking account positive results in the Copro-ELISA and the Copro-Western Blot tests.

${ }^{\mathrm{d}}$ more than 1 parasite agent can be present in a single sample.

$* \mathrm{p}<0.05$

the most common parasite association $(21.87 \%)$ was between A. caninum, T. vulpis, T. canis and U. stenocephala. Helminthic infections (89.13\%) were more frequent than protozoan $(13.04 \%)$.

\section{DISCUSSION}

According to worldwide studies conducted in recent years, the prevalence of intestinal parasites among dogs showed heterogeneous results: from $12.5 \%$ to $96 \%$ 17,30 . In countries where poor socioeconomic conditions were present and cultural habits were favorable to parasite transmission, high rates of infection were detected ${ }^{30}$. In contrast, surveys conducted in areas with adequate sanitary conditions showed that prevalence of intestinal parasites were lower than $33 \%{ }^{4,17}$. Some other factors such as geographical location, status of animal ownership, sampling protocols, demographic factors, anthelmintic usage, and diagnostic techniques are responsible for the wide range of endoparasite prevalence found ${ }^{16}$.

In Argentina several studies revealed parasite prevalence of $37.86 \%$ in Neuquén, $46.6 \%$ in Chubut and $77.4 \%$ in Salta, among others ${ }^{27,28,29}$. These results were below the parasite prevalence found in our investigation. Several researches about the socio-economic standard of living and the quality of life in the studied district, had analyzed indicators as education, health, housing, environment and access to public services, and had showed that $33 \%$ of the population is found in a poor socio-environmental condition because they live in the suburbs of the city with high incidence of unmet basic needs ${ }^{3}$. This situation added to the geographical characteristics and the wet weather of the region, and the cultural habits of the population can be favorable to parasite transmission ${ }^{32}$.

The present epidemiological investigation revealed that $A$. caninum was the most common parasite fol- lowed by T. canis, T. vulpis and U. stenocephala. These results agree with other findings in the same region ${ }^{19,25}$, but differ with these studies and with others conducted in the country with respect to the high prevalence of C. aerophila observed in the District of General Pueyrredón. This fact is relevant because this parasite is one of the least found in Argentina and also produces important diseases in $\operatorname{dogs}{ }^{31}$. As C. aerophila, the rest of parasites found in this study have zoonotic importance.

Geohelminths are involved in several human infections such as cutaneous larva migrans caused by $A$. canium and $U$. stenocephala, as well as visceral larva migrans and ocular larva migrans caused by $T$. canis ${ }^{1}$. T. vulpis is a parasite whose zoonotic potential is frequently disputed; nevertheless some researches reported visceral larva migrans syndrome and enteric trichurosis in adult people and children ${ }^{13,20}$.

The prevalence of protozoan diagnosed in the present study was lower than that reported by several authors ${ }^{4,16}$. The time elapsed before samples were used or/and the sedimentation method used to process them could affect the recovery of these parasitic agents.

The coproantigen tests used in this study to identify E. granulosus showed the presence of stray and domiciliary dogs with echinococcosis in the District of General Pueyrredón. This fact poses a severe threat to human health as E. granulosus is the causative agent of cystic echinococcosis, an important zoonoses in the southeast region of the Buenos Aires Province, included the district under study. Studies conducted in this region evidenced in the urban area a high number of cases of human hydatidosis and the existence of squares contaminated with E. granulosus eggs, and in the rural area $14.30 \%$ of bovine cattle with hydatid cysts and a prevalence of $16.60 \%$ of canine echinococcosis ${ }^{12}$.

The dogs infected with E. granulosus belonged to the center and to a periferic neighborhood of Mar 
del Plata city. As a consequence, these places could be identified as potentially risky areas ${ }^{5}$.

The coincidence of the finding of Taenid egg with a positive result to the coproantigen test in the same sample, confirms the presence of E. granulosus in this sample. The absence of Taenid eggs in the rest of the samples could be explained if we consider that conventional sedimentation and flotation methods have low sensitivity to recover Taenid eggs ${ }^{10}$. This is the first report of E. granulosus eggs in dog faeces in the District of General Pueyrredón

Most of faecal samples presented parasite associations in contrast with the results provided by other studies in the region ${ }^{25}$. The high prevalence of polyparasitized animals added to the zoonotic potential of the parasites found in the samples, mean that dog faeces could be the source of several parasite infections for the human and canine population of the region under study. Mixed infections also may play an important role in the epidemiology of parasitic disease because they reveal the proportion of dogs requiring combined drug treatment ${ }^{14}$.

The general parasite prevalence of stray and domiciliary dogs was high and similar. The specific prevalences were also similar between the two groups. Because stray dogs are often free-roaming, environmental contamination with parasite forms had likely already occurred over a fairly dispersed area, resulting in the presence of infectious stages that pose a risk of infection to pet dogs and to people who walk along these places. The high prevalence of domiciliary dogs with parasites showed the lack of veterinary care and the existence of risk factors for canine intestinal parasite infections to the dog owners who are possibly not aware of the zoonotic potential of the parasites carried by their dogs, or their mode of transmission to humans. To prevent or minimize zoonotic transmission dog owners should perform a responsibly care of their pets; in that way veterinary practitioners acting as information sources about canine zoonoses are also required ${ }^{14}$. It is also necessary that sanitary institutions take control measurements to prevent the increasing number of stray dogs and the huge contamination of the environment with faeces that they generate.

The comparison between males and females showed that the overall and the specific prevalences were alike, in agreement with similar studies ${ }^{6,14}$.

There is general consensus that the prevalence of intestinal parasites is higher in pups than in adults ${ }^{14}$. In our study there was no significant difference in the general parasite prevalence between the two age categories. Nevertheless all the parasites, except $C$. aerophila, showed higher prevalences in the youngest dogs, being A. caninum and T. vulpis the most significantly prevalent parasites in this group of dogs. Similar results were previously reported for A. caninum, T. canis and Giardia spp. ${ }^{9,14}$. Other study showed that young animals contained more frequently nematode eggs in faeces than adult animals ${ }^{22}$. Pups are at higher risk of infection due to transplacental and transmammary transmission, and parasite-specific immunity is usually acquired with age, probably as a consequence of single or repeated exposures ${ }^{24}$.

Taking into account the high parasite prevalence found and their zoonotic potential, the parasite zoonoses transmitted by dogs is still a sanitary problem in the District of General Pueyrredón. People are exposed to a broad spectrum of zoonotic parasites by means of environmental contamination with dog faeces. It is evident that the parasite control measurements applied are not enough and that the behavior of the human population favors the propagation of parasites. Consequently, a consistent and integral sanitary programme must be included in public health government actions to achieve the control of intestinal parasites in dogs.

Acknowledgments. The authors are grateful to Dr Eleonora Eugenia Kozubsky from the National University of La Plata for provides us a control sample of coccids and to Dr Martín Fugassa of the Biology Department from the National University of Mar del Plata, for technical assistance. We also thank Prof. Liliana Bordoni for revising this manuscript. This study formed part of the degree thesis of Lic. Carla Mariela Lavallén and the postdegree thesis of Dra. Marcela Cecilia Dopchiz.

\section{REFERENCES}

1. Alcaíno H, Gorman T. 1998. Enfermedades parasitarias transmitidas por el perro y el gato al hombre. In: Parasitología Médica (Atías A Ed.), $1^{\circ}$ ed., Mediterráneo, Santiago de Chile, p. 547-557.

2. Allan JC, Craig PS, García Noval J, Mencos F, Liu D, Wang Y, Wen H, Zhov P, Stringer R, Rogan M, Zehle E. 1992. Coproantigen detection for immunodiagnosis of Echinococcosis and Taeniasis in dogs and humans. Parasitol 104: 347-355.

3. Aveni SM. 2008. Geografía de la salud y calidad de vida: un análisis de la condición sanitaria en Mar del Plata. In: Territorio y calidad de vida, una mirada desde la geografía local (Lucero P Ed.), EUDEM, Mar del Plata, p. 229251.

4. Barutzki D, Schaper R. 2003. Endoparasites in dogs and cats in Germany 1999-2002. Parasitol Res 90: 148-150.

5. Bergagna H, Marasco M, Santillán G, Monkiewicz A, Verzoletti L, Céspedes G, Guarnera E. 2001. Utilización complementaria de copro-ELISA en el diagnóstico de la echinococcosis canina en la ciudad de Neuquén. Anales III Congreso Argentino de Zoonosis, II Congreso Latinoamericano de Zoonosis, Buenos Aires, Resúmenes: en CD.

6. Bridger KE, Whitney H. 2009. Gastrointestinal parasites in dogs from the Island of St. Pierre off the south coast of Newfoundland. Vet Parasitol 162: 167-170.

7. CDC. 2009. Center for Diseases Control and Prevention. Home Page. http://www.dpd.cdc.gov. 
8. Censo. 2010. http://www.censo2010.indec.gov.ar/preliminares/cuadro_resto.asp.

9. Claerebout E, Casaert S, Dalemans AC, De Wilde N, Levecke B, Vercruysse J, Jeurden T. 2009. Giardia and other intestinal parasites in different dog populations in Northern Belgium. Vet Parasitol 161: 41-46.

10. Craig PS. 1997. Immunodiagnosis of Echinococcus granulosus and a comparison of techniques for diagnosis of canine echinococcosis. In: Compendiun on cystic echinococcosis in Africa and middle eastern countries with special reference to Morocco (Andersen FL, Ouhelli H, Kachani M. Eds.), Brigham Young University Print Services, Utah, p. 85-118.

11. Craig PS, Macpherson CN. 2000. Dogs and cestode zoonoses. In: Dogs, zoonoses and public health (Macpherson CN, Mesli FX, Wandeler AI Eds.), CAB Internacional, Oxon, United Kingdom, p. 149-221.

12. Dopchiz MC. 2006. Aspectos epidemiológicos de la hidatidosis/echinococcosis en el sudeste de la Provincia de Buenos Aires. Tesis de Doctorado, Editorial Martín, Mar del Plata, p 201.

13. Dunn JJ, Columbus ST, Aldeen WE, Davis M, Carroll KC. 2002. Trichuris vulpis recovered from a patient with chronic diarrhea and five dogs. J Clin Microbiol p. 2703 2704.

14. Fontanarrosa MF, Vezzani D, Basabe J, Eiras, DF. 2006. An epidemiological study of gastrointestinal parasites of dogs from southern greater Buenos Aires (Argentina): age, gender, breed, mixed infections, and seasonal and spatial patterns. Vet Parasitol 136: 283-295.

15. Guarnera EA, Santillán G, Botinelli R, Franco A. 2000. Canine echinococcosis: an alternative for surveillance epidemiology. Vet Parasitol 88: 131-134.

16. Katagiri S, Oliveira-Sequeira TC. 2008. Prevalence of dog intestinal parasites and risk perception of zoonotic infection by dog owners in Sao Paulo State, Brazil. Zoonoses Public Health 55: 406-413.

17. Little SE, Johnson EM, Lewis D, Jaklitsch RP, Payton ME, Blagburn BL, Bowman DD, Moroff S, Tams T, Rich L, Aucoin D. 2009. Prevalence of intestinal parasites in pet dogs in the United States. Vet Parasitol 166: 144-152.

18. Macpherson CN. 2005. Human behaviour and the epidemiology of parasitic zoonoses. Int J Parasitol 20: 1-13.

19. Madrid V, Sardella N, Denegri G, Hollmann P. 2005. Contaminación de playas de la ciudad de Mar del Plata con parásitos de importancia sanitaria. In: Mar del Plata, fragilidad costera (Isla FI, Denegri G, Cermelo L, Farias A, Crowder P. Eds.), ed. Martín, Mar del Plata, p. 21-33.

20. Masuda Y, Kishimoto T, Ito H, Tsuji M. 1987. Visceral larva migrans caused by Trichuris vulpis presenting as a pulmonary mass. Thorax 42: 990-991.
21. Méndez O. 1998. Lecciones prácticas sobre enteroparasitosis humanas. Suplemento Acta Bioquímica Clínica Latinoamericana, ed. Federación Bioquímica de la Provincia de Buenos Aires, La Plata, p 163.

22. Oliveira-Sequeira TC, Amarante AF, Ferrari TB, Nunes LC. 2002. Prevalence of intestinal parasites in dogs from São Paulo State, Brazil. Vet Parasitol 103: 1927.

23. Pértega Díaza S, Pita Fernández S. 2004. Asociación de variables cualitativas: el test exacto de Fisher y el test de Mcnemar. Atención primaria en la red 1-7, www.fisterra. com.

24. Ramírez Barrios RA, Barboza Mena G, Muñoz J, Angulo Cubillán F, Hernández E, González F, Escalona F. 2004. Prevalence of intestinal parasites in dogs under veterinary care in Maracaibo, Venezuela. Vet Parasitol 121: $11-20$.

25. Riva E, Sardella N, Hollmann P, Denegri G. 2006. Relevamiento coproparasitológico de aceras y calles de la ciudad de Mar del Plata, Argentina. Rev Vet 17: 72-76.

26. Rodríguez F, Denegri G, Sardella N, Hollmann P. 2005. Relevamiento coproparasitológico de caninos ingresados al Centro Municipal de Zoonosis de Mar del Plata, Argentina. Rev Vet 16: 9-12.

27. Sánchez Thevenet P, Jensen O, Mellado I, Torrecillas C, Raso S, Flores ME, Minvielle MC, Basualdo JA. 2003. Presence and persistence o f intestinal parasites in canine fecal material collected from the environment in the Province of Chubut, Argentine Patagonia. Vet Parasitol 117: 263-269.

28. Soriano SV, Pierangeli NB, Roccia I, Bergagna HF, Lazzarini LE, Celescinco A, Saiz MS, Kossman A, Contreras PA, Arias C, Basualdo JA. 2010. A wide diversity of zoonotic intestinal parasites infects urban and rural dogs in Neuquén, Patagonia, Argentina. Vet Parasitol 167: 81-85.

29. Taranto NJ, Passamonte NJ, Marinconz R, De Marzi MC, Cajal SP, Malchiodi EL. 2000. Parasitosis zoonóticas transmitidas por perros en el Chaco Salteño. Medicina 60: 217-220.

30. Traub RJ, Robertson ID, Irwin P, Mencke N, Thompson RC. 2003. Humans, dogs and parasitic zoonoses-Unravelling the relationships in a remote endemic community in northeast India using molecular tools. Parasitol Res 90: 156-157.

31. Venturini L, Radman N. 1986. Capillariosis de vías aéreas de caninos. Rev Avepa 4: 23.

32. Wisnivesky-Colli C. 2003. Ecología y epidemiología de las infecciones parasitarias, ed. LUR, Cartago (Costa Rica), p 400. 